\title{
Lipid Accumulation of Macadamia Nuts during Kernel Development
}

\author{
Koaze Hiroshi*, Karanja Paul N.**, Kojima Michiyuki* \\ BABA Naomichi** and IsHIBASHI Ken-ichi* \\ * Obihiro University of Agriculture and Veterinary Medicine \\ Inada, Obihiro-shi, Hokkaido 080-8555 \\ * * Faculty of Agriculture, Okayama University \\ 1-1-1, Tsushimanaka, Okayama-shi, Okayama 700-8530
}

\begin{abstract}
Macadamia nuts at four different stages of development, namely 3, 5, 7 and 9 months after flowering were examined for their physical and physiological characteristics. There were no significant differences among shell sizes and nut-in-shell weight at different growth stages. However, moisture contents were remarkably different among different development stages. Kernel of 3 month stage contained remarkably high amount of moisture and low total lipids $(\mathrm{P}<0.05)$. A remarkable decrease in moisture observed from 5 months after flowering, while total lipids significantly increased. The major lipid classes were found to be triacylglycerols for neutral lipids, and phosphatidylcholine and phosphatidylethanolamine for polar lipids at all development stages. The composition of polar lipids changed remarkably during kernel development, especially after 3 months. Fatty acid composition of total lipids at 3 months stages showed significantly higher amounts of myristic, palmitic and linoleic acid $(P<0.05)$, while contents of stearic and oleic acid increased as the nuts grew further. A ratio of unsaturated to saturated fatty acid contents changed from 4.3 to 6.6 with kernel development and this was mainly due to an increase in oleic acid.
\end{abstract}

(Received Nov. 12, 2001 ; Accepted Mar. 4 ,2002)

Macadamia genus belongs to the botanical family Proteaceae originated from Australia. There are only 2 out of about 10 species, Macadamia tetraphylla and integrifolia, which produce edible nuts and these two species are also known as rough-shell and smoothshell type, respectively, from their characteristic surface texture of the shells. The evergreen macadamia tree grows to about $10 \mathrm{~m}$ in height and start bearing nuts at an age of 5 to 7 years. The nut production is said to continue up to 60 years and this provides a long-term harvest for farmers. The nuts can be harvested all through a year, having a peak harvest season of 2 to 3 months (CAVALETTO1), SHIGEURA and OOKA ${ }^{21}$, MASON and MCCONACHIE ${ }^{3)}$ ).

Tree nuts are known to have dietary benefits over other food resources and recently this kind of benefits attracts a lot of medical and dietary interests. The major nutrient of macadamia nuts is oil consisting of more than $70 \%$ of kernel when it is fully matured. It is also well known to contain the highest amount of monounsaturated fatty acids and negligible amount of cholesterols. Some reports on nutritional superiority of the nuts suggest that macadamia oil is potentially beneficial on cholesterol and low-density lipoprotein cholesterol levels, according to CURB et al. ${ }^{4)}$ and AKO et al..$^{5)}$ Furthermore, the oil is reported to be relatively stable due to high concentration of monounsaturated fatty acid composition as reported by KAJJSER et al ${ }^{6)}$

ZLATANOV et al. ${ }^{7)}$ carried out studies on phospholipids of almond, hazelnut and walnuts, which are commonly used in Bulgaria and they reported that major phospholipids of these nuts were phosphatidylcholine, phosphatidylinositol and phosphatidylethanolamine with a predominant fatty 
acid of linoleic acid. They also reported that higher quantities of saturated fatty acids were contained in phospholipids of these nut oils. During development of nuts, a number of reports showed a sudden accumulation of oil. For hazel nuts, a sharp rise in oil content was observed in early July, in which growth was initiated in late May and expected to reach full maturity in late August. During kernel development of hazel nuts, fatty acid composition is reported to change considerably, according to PARCERISA et al ${ }^{8)}$ Although JONES and SHAW ${ }^{9}$ reported sudden increase in macadamia oil content during growth on 111 days after flowering and continuous accumulation of oil towards a full maturity (215 days), there is not enough scientific information available on oil accumulation of macadamia nuts during kernel development. Furthermore, mature nuts of macadamia and hazel nuts are usually harvested when they drop naturally from a tree after reaching a full maturity. When immature macadamia nuts are mixed with mature nuts, immature nuts can be separated only after a full processing operation of drying and cracking is applied, due to the presence of hard brown shells and immature nuts lower quality of final products such as roast macadamia nuts. Hence, it is important to study quality changes during nut growth for development of nut separators and use of immature nuts in future.

In the present study, the main objective was to show changes associated with oil accumulation from early stages of kernel development to a full maturation. Thus, we investigated into changes in sizes, weight, kernel content, moisture and total lipid contents, lipid classes and fatty acid composition during kernel development of macadamia nuts.

\section{Materials and Methods}

\section{Materials}

Macadamia nuts (Macadamia integrifolia) with four different maturation stages were obtained from a farm managed by a private nut processing factory in Kenya in August 2000. All nuts were grown under the same climatic conditions and agricultural practices. Nineteen in-shell nuts were harvested at 3 months after flowering, 17 nuts each for 5 and 7 months old, and 19 nuts for 9 months old, which is assumed to be equivalent to a fully matured stage. Nuts of up to 7 months old in this study were all contained in green outer husks and most of 9 months old nuts were covered with much thinner cracked husk whose color had turned to brown. When nuts reach a full maturity, the green outer husk starts drying up, becomes thinner and eventually cracks to release nuts-in-shell. Those nuts covered with green husks were carefully removed by cutting husks with a knife. The in-shell nuts were thoroughly washed with clean running water, excess water remaining on the shell surface was wiped out with a dry cotton cloth and the in-shell nuts were left for drying at room temperature for 2 $\sim 3$ hours. Individual in-shell nuts were packed in separate plastic bags and kept frozen at $-20^{\circ} \mathrm{C}$ until chemical analyses were carried out.

\section{Physical parameters}

Prior to chemical analyses, size of a shell was determined by measuring two diameters defined as "length" being a diameter along a crease line on the surface of the shell and "width" as a diameter at the center of the crease line and normal to the line. Kernel was then extracted from the nut-in-shell by cracking the shell carefully for chemical analyses. Weights of a nut-in-shell and a kernel extracted were recorded and percent kernel weight divided by corresponding nutin-shell weight was reported as kernel content.

\section{Moisture content}

A quarter portion of a single kernel was dried at 95 $-100^{\circ} \mathrm{C}$ under vacuum below $100 \mathrm{mmHg}$ for the determination of moisture content until no more weight change was detected $\left(\mathrm{AOAC}^{10)}\right)$.

\section{Total lipid content and lipid classes}

Total lipid was extracted from the remaining portion of single kernel with a mixture of chloroform and methanol $(2: 1, \mathrm{v} / \mathrm{v})$. The solvent used was evaporated in a centrifugal vacuum evaporator and dried in a desiccator under vacuum. Evaporation and vacuum drying were repeated until no more changes in weight were detected. The determination was repeated in triplicate for all samples. Total lipid extracted was further applied to a thin layer chromatography plate of $0.25 \mathrm{~mm}$ layer of silica gel 60 (Merck) for classification of neutral and polar lipids. 
Mixed solvents used were hexane/diethyl ether/ acetic acid $(80: 20: 1, \mathrm{v} / \mathrm{v})$ for neutral lipids and chloroform/methanol/water $(65: 25: 4, \mathrm{v} / \mathrm{v})$ for polar lipids. Chromatography plates were sprayed with $\mathrm{H}_{2} \mathrm{SO}_{4}$ and heated in an oven. Spots developed were quantified by a densitometer (Densitograph Lumino-CCD, ATTO Corp.) and identified by comparison of $\mathrm{R}_{\mathrm{f}}$ values with that of known standards (Funakoshi Co.) and color developed.

\section{Fatty acid composition}

Total lipid extracted was converted to their methyl esters with $5 \% \mathrm{HCl}-m e t h a n o l$. A Shimadzu Model $\mathrm{GC}-14 \mathrm{~A}$ gas chromatograph equipped with a flame ionization detector was used for the determination of fatty acid composition at constant column temperature of $200^{\circ} \mathrm{C}$ and nitrogen carrier gas at 2.63 $\mathrm{kg} / \mathrm{cm}^{2}$. The column used was Shinchrom E 71 packed with $5 \%$ Shimalite $80-100 \mathrm{AW}$ (Shimadzu) in $3.1 \mathrm{~m}$-length $\times 3.2 \mathrm{~mm}$-inner diameter. The determination was repeated in triplicate. The resultant peaks were compared for their retention times with the peaks obtained from known standard fatty acid methyl esters $(189-4,189-17$ and M3378, Sigma).

\section{Statistical analysis}

Data collected were examined for significance of differences among samples at $\mathrm{P}<0.05$ level by Duncan's multiple range tests with SPSS for Windows (Release 6.1.3, 1995).

\section{Results and Discussion}

\section{Kernel development}

There were no significant differences observed after Duncan's multiple range tests applied to examine significant differences among sizes and weight of in-shell nuts as shown in Table 1. This indicates clearly that macadamia nuts can achieve the maximum size and weight within 3 months after flowering and for the rest of the growth period up to a full maturity, quality development such as an increase in solids and oil accumulation takes place. It is also noted from Table 1 that kernel content decreased significantly from 5 months stage $(\mathrm{P}<0.05)$ and became almost constant towards the full maturity stage, while there is no significant change in nut-inshell weight. This seems to be due to hardening of shell as well as quality development of kernels, namely an increase in solid content, after 3 months stage. In fact, the color of shell changed from white at 3 months stage to lighter brown at 5 months, later to darker brown, during the development.

\section{Moisture and total lipid contents}

As shown in Table 2, a drastic drop in moisture content was observed during development, where more than $90 \%$ of moisture was contained at the early stage of development, moisture content was reduced to approximately $30 \%$ after 5 months and further to $14 \%$ at the full maturity. Table 2 also indicated that total lipid contents changed in a completely opposite manner, comparing with the changes in moisture contents, where a sudden increase in total lipids from $1.12 \%$ at 3 months stage to $47.47 \%$ at 5 months was observed. Although there was no significant difference in total lipid contents between 5 and 7 months stages $(P<0.05)$, the total lipid content reached the highest amount of more than $60 \%$ at the

Table 1 Changes in Size, Nut-in-Shell Weight, Kernel Weight and Kernel Content during Development of Macadamia Nuts

\begin{tabular}{c|c|c|c|c|c}
\hline $\begin{array}{c}\text { Development Stage } \\
(\text { months })\end{array}$ & $\begin{array}{c}\text { Length } \\
(\mathrm{cm})\end{array}$ & $\begin{array}{c}\text { Widths } \\
(\mathrm{cm})\end{array}$ & $\begin{array}{c}\text { Nut-in-shell Weight }{ }^{\text {nd }} \\
(\mathrm{g})\end{array}$ & $\begin{array}{c}\text { Kernel Weight } \\
(\mathrm{g})\end{array}$ & $\begin{array}{c}\text { Kernel Content } \\
(\%)\end{array}$ \\
\hline 3 & $2.75 \pm 0.04$ & $2.67 \pm 0.04$ & $9.46 \pm 0.45$ & $3.89^{\mathrm{b}} \pm 0.21$ & $41.00^{\mathrm{b}} \pm 0.67$ \\
\hline 5 & $2.52 \pm 0.02$ & $2.55 \pm 0.03$ & $9.06 \pm 0.26$ & $3.25^{\mathrm{a}} \pm 0.12$ & $35.79^{\mathrm{a}} \pm 0.69$ \\
\hline 7 & $2.58 \pm 0.05$ & $2.65 \pm 0.06$ & $10.26 \pm 0.65$ & $3.62^{\mathrm{ab}} \pm 0.25$ & $35.17^{\mathrm{a}} \pm 0.72$ \\
\hline 9 & $2.55 \pm 0.03$ & $2.67 \pm 0.04$ & $9.81 \pm 0.41$ & $3.54^{\mathrm{ab}} \pm 0.16$ & $36.27^{\mathrm{a}} \pm 0.87$ \\
\hline
\end{tabular}

Mean \pm standard error

${ }^{\text {nsd }}$ means that there is no significant difference at $5 \%$ level.

Means with different letters indicate significant difference at $5 \%$ level. 
full maturity.

JONES and SHAW ${ }^{9}$ reported that fresh weight of nuts changed from $1.14 \mathrm{~g}$ on 90 days after flowering, to $3.14 \mathrm{~g}$ on 136 days and $2.78 \mathrm{~g}$ on 215 days (full maturity), while dry solid contents changed from 5 to $67.7 \%$ during this period of nut development. The results obtained from the present study also showed similar tendency where solid contents changed from very low amount of $10 \%$ to $86 \%$, while the fresh weight has reached its maximum weight at relative early stage of growth. Furthermore, the present study indicated that a marked change in total lipid content was observed between 3 and 5 months after flowering. This is very similar to Jones and Shaw's study where they indicated a marked change observed between 90 and 111 days. ZLATANOv et al.$^{\text {? }}$ reported the total lipid contents of common Bulgarian nuts, namely, almond with $63.9 \%$, hazel nuts with $53.9 \%$ and walnuts with $68.5 \%$. MASON and WILLIS ${ }^{\text {11 }}$ reported relationships amongst specific gravity of macadamia kernels and oil content, kernel size and

Table 2 Changes in Moisture Content and Total Lipid Content during Development of Macadamia Nuts

\begin{tabular}{c|c|c}
\hline $\begin{array}{c}\text { Development Stage } \\
\text { (months) }\end{array}$ & $\begin{array}{c}\text { Moisture Content } \\
(\%)\end{array}$ & $\begin{array}{c}\text { Total Lipid Content } \\
(\%)\end{array}$ \\
\hline 3 & $90.26^{\mathrm{c}} \pm 0.59$ & $1.12^{\mathrm{a}} \pm 0.18$ \\
\hline 5 & $29.50^{\mathrm{b}} \pm 1.13$ & $47.47^{\mathrm{b}} \pm 1.01$ \\
\hline 7 & $31.35^{\mathrm{b}} \pm 1.72$ & $47.88^{\mathrm{b}} \pm 1.03$ \\
\hline 9 & $14.13^{\mathrm{a}} \pm 1.55$ & $60.84^{\mathrm{c}} \pm 1.10$ \\
\hline
\end{tabular}

Mean \pm standard error

Means with different letters indicate significant difference at $5 \%$ level. roasting quality of the kernels. They concluded that with an increase in specific gravity, kernels became smaller in size and contained less oil. From the results shown in Table 2, mature nuts contained less moisture and highest amount of total lipid and this may agree with the conclusion by Mason and Willis, since low moisture content with high total lipid content leads to lower specific gravity.

\section{3 . Neutral and polar lipid classes}

Table 3 and 4 show the classes of neutral and polar lipids identified, respectively, and their changes during kernel development. The major classes of macadamia nuts were found to be triacylglycerols for neutral lipids and phosphatidylcholine and phosphatidylethanolamine for polar lipids throughout the kernel development.

Several studies on polar lipids of nuts were reported recently. ZLATANOV et al. ") reported major polar lipids of nuts commonly consumed in Bulgaria. Their results indicated that phosphatidylcholine was the major phospholipid for almond and hazelnut, and phosphatidylinositol as the secondary for almond, and phosphatidylinositol and phosphatidylethanolamine for hazel nuts. In walnut, phosphatidylinositol was the major, while phosphatidylcholine as the secondary phospholipid. PARCERISA et al ${ }^{8)}$ conducted a study on triacylglycerols and polar lipids of hazel nuts and reported that there was a sharp decrease in polar lipids during growth. From the present study, a sharp decline of polar lipid content during kernel development was also observed. The initial polar lipid content in total lipid was $3.44 \%$ and this decreased to $2.03 \%$ at 5 months stage, $3.17 \%$ at 7 months and

Table 3 Changes in Neutral Lipid Classes during Development of Macadamia Nuts

\begin{tabular}{|c|c|c|c|c|c|c|c|c|}
\hline Months & Waxes $^{1}$ & Triacylglycerols & $\begin{array}{c}\text { Free fatty } \\
\text { acids }\end{array}$ & $\begin{array}{c}\text { Fatty } \\
\text { alcohols }\end{array}$ & Sterols & $\begin{array}{l}\text { Oleanolic } \\
\text { acids }\end{array}$ & Monoacylglycerols $^{\text {nsd }}$ & Polar lipids \\
\hline 3 & $11.12^{\mathrm{c}} \pm 1.35$ & $64.53^{\mathrm{a}} \pm 2.20$ & $3.92^{\mathrm{c}} \pm 0.34$ & $0.65^{\mathrm{a}} \pm 0.16$ & $7.52^{c} \pm 0.79$ & $8.72^{\mathrm{c}} \pm 0.76$ & $0.85 \pm 0.17$ & $3.44^{\mathrm{b}} \pm 0.43$ \\
\hline 5 & $4.29^{b} \pm 0.49$ & $82.80^{b} \pm 1.09$ & $3.05^{\mathrm{b}} \pm 0.32$ & $0.50^{\mathrm{b}} \pm 0.08$ & $3.51^{a} \pm 0.43$ & $3.64^{\mathrm{a}} \pm 0.59$ & $0.18 \pm 0.09$ & $2.03^{\mathrm{a}} \pm 0.20$ \\
\hline 7 & $3.71^{\mathrm{ab}} \pm 0.53$ & $78.69^{b} \pm 1.55$ & $2.77^{\mathrm{b}} \pm 0.30$ & $0.38^{\mathrm{b}} \pm 0.11$ & $5.38^{\mathrm{b}} \pm 0.50$ & $5.91^{\mathrm{b}} \pm 0.45$ & trace & $3.17^{\mathrm{b}} \pm 0.22$ \\
\hline 9 & $1.86^{\mathrm{a}} \pm 0.28$ & $87.25^{c} \pm 0.83$ & $0.08^{a} \pm 0.06$ & trace & $4.30^{\mathrm{ab}} \pm 0.32$ & $3.75^{\mathrm{a}} \pm 0.31$ & $0.03 \pm 0.03$ & $2.73^{\mathrm{ab}} \pm 0.15$ \\
\hline
\end{tabular}

Mean \pm standard error

${ }^{\text {nsd }}$ means that there is no significant difference at $5 \%$ level.

Means with different letters indicate significant difference at $5 \%$ level.

${ }^{1}$ Waxes includes sterol esters and hydrogen carbons. 
finally to $2.73 \%$ at 9 months full maturity stage as shown in Table 3 . With the advancement of kernel development and resultant accumulation of the total lipid, the composition of polar lipid classes converges to more predominant phosphatidylethanolamine and phosphatidylcholine as seen from Table 4 . The minor components in polar lipids appeared at 3 months stage may have important roles particularly in kernel development at early stages.

\section{Fatty acid composition}

Table 5 shows changes in fatty acid composition of total lipids during the kernel development. The major fatty acids were monounsaturated fatty acids such as palmitoleic and oleic acid throughout the development. There was a significant decrease in shorter chain fatty acids such as myristic, palmitic and palmitoleic acids, mostly at earlier stage of development, while stearic and oleic acids increased with advancement of kernel development $(P<0.05)$. Polyunsaturated fatty acids such as linoleic and linolenic acids decreased during kernel development. A ratio of unsaturated to saturated fatty acids changed drastically from 4.3 at 3 months stage to 7.4 at 5 months and finally to 6.6 at the full maturity. This change was mainly caused from the increase in oleic acid and decrease in saturated fatty acids such as myristic and palmitic acid during the development as shown in Table 5 . SAlEEB et al ${ }^{12)}$ reported fatty acid composition of macadamia nuts from several cultivars and hybrids. In the present study, fatty acid composition was almost in agreement with those reported by SALEEB et al. BEUCHAT and WORTHINGTON ${ }^{13}$ reported a ratio of unsaturated to saturated fatty acid composition as 6.0 , which was very close to the result obtained in the present study. JONES and SHAW ${ }^{9}$ suggested that shorter saturated fatty acids accumulated at early stages of oil synthesis of macadamia nuts, followed by formation of long chain unsaturated fatty acids. This may explain the change in a ratio of unsaturated-saturated fatty acid

Table 4 Changes in Polar Lipid Classes during Development of Macadamia Nuts

\begin{tabular}{c|c|c|c|c|c|c|c}
\hline Months & $\begin{array}{c}\text { Acylsteryl- } \\
\text { glucosides }\end{array}$ & $\begin{array}{c}\text { Monoglycosyl } \\
\text { diglycerides }\end{array}$ & $\begin{array}{c}\text { Steryl- } \\
\text { glucosides }\end{array}$ & Cerebrosides & $\begin{array}{c}\text { Phosphatidyl- } \\
\text { ethanolamine }\end{array}$ & $\begin{array}{c}\text { Phosphatidyl- } \\
\text { choline }\end{array}$ & $\begin{array}{c}\text { Phophatidyl- } \\
\text { inositol }^{2}\end{array}$ \\
\hline 3 & $16.32^{\mathrm{b}} \pm 2.28$ & $3.33^{\mathrm{b}} \pm 1.19$ & $4.51^{\mathrm{b}} \pm 1.11$ & $15.76^{\mathrm{b}} \pm 3.18$ & $19.63^{\mathrm{a}} \pm 2.29$ & $18.24^{\mathrm{a}} \pm 1.84$ & $4.38^{\mathrm{b}} \pm 2.04$ \\
\hline 5 & $24.69^{\mathrm{c}} \pm 1.09$ & $0.87^{\mathrm{a}} \pm 0.70$ & $2.20^{\mathrm{ab}} \pm 0.80$ & $9.62^{2 \mathrm{~b}} \pm 2.01$ & $39.48^{\mathrm{b}} \pm 1.61$ & $23.51^{\mathrm{ab}} \pm 1.45$ & $0.67^{\mathrm{a}} \pm 0.49$ \\
\hline 7 & $18.27^{\mathrm{b}} \pm 2.32$ & trace & $3.33^{\mathrm{ab}} \pm 0.60$ & $7.75^{\mathrm{a}} \pm 1.09$ & $41.23^{\mathrm{b}} \pm 2.51$ & $27.33^{\mathrm{b}} \pm 1.96$ & trace \\
\hline 9 & $5.60^{\mathrm{a}} \pm 1.40$ & trace & $1.01^{\mathrm{a}} \pm 0.57$ & $7.20^{\mathrm{a}} \pm 1.23$ & $55.89^{\mathrm{c}} \pm 2.11$ & $27.84^{\mathrm{b}} \pm 1.51$ & trace \\
\hline
\end{tabular}

Mean \pm standard error

Means with different letters indicate significant difference at $5 \%$ level.

${ }^{1}$ Phosphatidyl ethanolamine includes Diglycosyl diglycerides.

${ }^{2}$ Phophatidyl inositol includes Sulfoquinovosyl diacylglycerosl.

Table 5 Changes in Percent Fatty Acid Composition of Total Lipids during Development of Macadamia Nuts

\begin{tabular}{c|c|c|c|c|c|c|c|c|c|c}
\hline $\begin{array}{c}\text { Development } \\
\text { Stage } \\
\text { (months) }\end{array}$ & $\begin{array}{c}\text { Myristic } \\
\text { acid }\end{array}$ & $\begin{array}{c}\text { Palmitic } \\
\text { acid }\end{array}$ & $\begin{array}{c}\text { Palmitoleic } \\
\text { acid }\end{array}$ & $\begin{array}{c}\text { Stearic } \\
\text { acid }\end{array}$ & Oleic acid & $\begin{array}{c}\text { Linoleic } \\
\text { acid }\end{array}$ & $\begin{array}{c}\text { Linolenic } \\
\text { acid }\end{array}$ & $\begin{array}{c}\text { Arachidic } \\
\text { acid }\end{array}$ & $\begin{array}{c}\text { Eicosenoic } \\
\text { acid }\end{array}$ & $\begin{array}{c}\text { Ratio of } \\
\text { unsaturated } \\
\text { to saturated } \\
\text { fatty acids }\end{array}$ \\
\hline 3 & $2.20^{b} \pm 0.16$ & $15.32^{b} \pm 0.69$ & $37.57^{b} \pm 0.84$ & $1.06^{a} \pm 0.19$ & $28.17^{a} \pm 1.84$ & $11.63^{b} \pm 1.48$ & $3.13 \pm 0.56$ & $0.46 \pm 0.14$ & $0.46^{a} \pm 0.15$ & 4.25 \\
\hline 5 & $1.23^{a} \pm 0.17$ & $8.89^{a} \pm 0.21$ & $37.30^{b} \pm 0.94$ & $1.41^{a} \pm 0.11$ & $46.86^{b} \pm 0.94$ & $2.61^{a} \pm 0.23$ & trace & $0.38 \pm 0.12$ & $1.33^{b} \pm 0.21$ & 7.40 \\
\hline 7 & $1.63^{a} \pm 0.22$ & $8.95^{\mathrm{a}} \pm 0.29$ & $36.37^{b} \pm 0.76$ & $1.41^{\mathrm{a}} \pm 0.12$ & $47.80^{b} \pm 1.12$ & $2.74^{a} \pm 0.23$ & trace & $0.26 \pm 0.11$ & $0.85^{\mathrm{a}} \pm 0.15$ & 7.16 \\
\hline 9 & $1.29^{\mathrm{a}} \pm 0.12$ & $9.80^{\mathrm{a}} \pm 0.33$ & $30.19^{\mathrm{a}} \pm 0.77$ & $1.77^{\mathrm{b}} \pm 0.13$ & $53.62^{\mathrm{c}} \pm 0.74$ & $2.32^{\mathrm{a}} \pm 0.12$ & trace & $0.35 \pm 0.09$ & $0.66^{\mathrm{a}} \pm 0.15$ & 6.57 \\
\hline
\end{tabular}

Mean \pm standard error

${ }^{\text {nsd }}$ means that there is no significant difference at $5 \%$ level.

Means with different letters indicate significant difference at $5 \%$ level. 
composition during kernel development as shown in this study. ZLATANOv et al. ${ }^{7}$ reported major fatty acids found in three types of nuts commonly used in Bulgaria and the major fatty acid was reported to be linoleic acid. Studies on fatty acid composition of total lipid, polar and non-polar lipid classes may lead to oil synthesis pathway. PARCERIS et al. . $^{\text {) }}$ investigated changes in fatty acid composition of polar and nonpolar lipids during development of hazel nuts. They have reported that there was a steep decrease in phospholipids during development and ratios of unsaturated to saturated fatty acids of polar and nonpolar lipids were significantly different. GUMMERSON $e t$ al. ${ }^{14)}$ attempted to show the possible participation of acyl-ACP desaturase to form palmitoleic acid, which is a unique monounsaturated fatty acid highly contained in macadamia nuts. However, the oil synthesis pathway is not yet clearly explained and there are needs to collect more biochemical information.

\section{Conclusion}

This study was conducted to analyze parameters associated with oil accumulation of macadamia nuts and the results indicated that very high biochemical activities related to oil synthesis might be taking place around 3 months after flowering. The compositions of polar lipids and fatty acids at 3 months stage were remarkably different from those at the full maturity, while diameters and weight had reached maximum values even after 3 months. Therefore, it seems to be difficult to separate immature nuts from a mixture with mature nuts by their appearance and size. From this view, it is highly desirable to develop separators for non-destructive identification of immature nuts from the mixture. The results on the changes in lipid accumulation during the kernel development discovered in the present study should contribute a lot to develop this kind of non-destructive separators, since such devices often employ spectrometric detection of specified chemical components in samples. Our present study also suggests that, since there are slow but gradual changes in quality and quantity of oil taking place from 5 months to the full maturity, the nuts of full maturity should be carefully selected for nut processing in order to obtain the highest possible quality.

Acknowledgement The authors are indebted to Kenya Nuts Co. for their kind donation of macadamia sample and technical advice.

\section{Reference}

1) Cavaletto, C. G. : Handbook of Tropical Foods (Dekker, New York), pp. 361 397 (1983)

2 ) Shigeura, G. T. and OOKA, H. : Research Extension Series 039 (College of Tropical Agriculture and Human Resources, University of Hawaii) (1984)

3 ) Mason, R. L. and McConachie, I. : Food Australia, $46(10), 466 \sim 471$ (1994)

4 ) Curb, J. D., Wergowske, G., Dobbs, J. C., AbBott, R. D. and HuANG, B. : Arch. Intern. Med., 160, 1154 $\sim 1158$ (2000)

5 ) Ako, H., OKudA, D. and Gray, D. : Nutrition, 11, 286 〜288 (1995)

$6)$ Kaijser, A., Dutta, P. and Savage, G. : Food Chem., 71, 67 70 (2000)

7 ) Zlatanov, M., Ivanov, S. and Aitzetmuller, K. : Fett/Lipid, 11, 437〜439 (1999)

8 ) Parcerisa, J., Codony, R., Boatella, J. and RAFECAS, M. : J. Agric. Food Chem., 47, 1410 1415 (1999)

9) Jones, W. W. and Shaw, L. : Plant Physiol., 18 ( 1 ), $1 \sim 7$ (1943)

10) The Association of Official Analytical Chemists : Official Methods of Analysis of the Assoc. Offic. Anal. Chemists, 16th edition (1995)

11) Mason, R. L. and Wills, R. B. H. : Food Technol. Aust., 35 ( 5 ), 245 248 (1983)

12) Saleeb, W. F., Yermanos, D. M., Huszar, C. K., Storey, W. B. and Labanauskas, C.K. : J. Amer. Soc. Hort. Sci., 98 ( 5 ), 453 456 (1973)

13) Beuchat, L. R. and Worthington, R. E. : J. Food Technol., 13, 355 358 (1978)

14) Gummerson, P. O., Lenman, M., Lee, M., Singh, S. and Stymne, S. : Plant Science, 154, 53 60（2000） 


\section{マカダミアナッツ仁果の成長中の脂質蓄積}

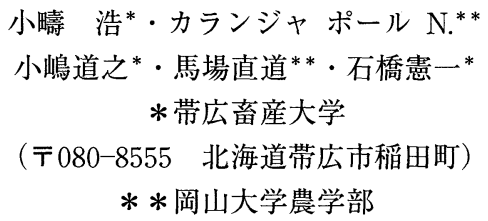

近年，一価不飽和脂肪酸を含む植物性食品が，コレ ステロール低下に寄与することが知られ，注目を集め ている。また, 多価不飽和脂肪酸と異なり, 一価の不 飽和脂肪酸は, 調理中の加熱酸化に対して比較的安定 であるとの報告もあり，これらの一価不飽和脂肪酸を 多く含有するナッツ類等植物油の有用性が指摘されて いる。マカダミアナッツは, オレイン酸やパルミトオ レイン酸といった，一価の不飽和脂肪酸を $80 \%$ 近く含 有するが，コレステロールは含まれないことが知られ ている。本報では，このように栄養機能的にも関心の 高まりつつあるマカダミアナッッの成長中の脂質蓄積 状況を追跡し, 脂質画分や脂肪酸組成の成長中の変化 を検討した。ナッツを含有する殸の大きさや重量は, 開花後 3 カ月で，すでに完熟果と差のないまでに成長
していた。しかし，含水率や全脂質含量では大きな差 がみられ， 3 力月以降に急激な含量変化が生じ，その 後，完熟までの間に，徐々に最終品質が形成されてい った。つまり，開花後 3 力月時に， $1.12 \%$ 程度の全脂 質含量と $90 \%$ 以上の含水率であったナッツが, 完熟時 には， $60 \%$ 以上の全脂質含量，14\%の含水率となった。 このような成長中の脂質蓄積には，さまざまな醳素や 合成経路が関与しており，その解明には多くの情報が 必要となるが，ここでは，構成脂肪酸，中性脂質と極 性脂質の画分の変化を報告した。開花後 3 力月目に は，36\%もの極性脂質が含有され，その構成も，ホス ファチジルコリン，ホスファチジルエタノールアミン を主体に，糖脂質も含まれていた。しかし，完熟に近 づくにつれて，ホスファチジルコリン，ホスファチジ ルエタノールアミンを中心とした，比較的単純な組成 に変化していった。中性脂質においては, トリアシル グリセロールが主要構成分であった。一方, 構成脂肪 酸は, 3 カ月時には, ミリスチン酸, パルミチン酸, リノール酸の含量が高く, オレイン酸は, $28 \%$ 程度で あった。ナッツの完熟時期に近づくにつれ，オレイン 酸含量が上昇し, 不飽和・飽和脂肪酸比も, 3 力月時 の4.3から完熟時の6.7へと著しく变化した。

(平成13年11月 12 日受付，平成14年 3 月 6 日受理) 